\title{
Diallyl disulfide inhibits the proliferation of HT-29 human colon cancer cells by inducing differentially expressed genes
}

\author{
YOU-SHENG HUANG ${ }^{1,2}$, NA XIE ${ }^{1,2}$, QI SU ${ }^{1}$, JIAN SU $^{1}$, CHEN HUANG $^{1}$ and QIAN-JIN LIAO ${ }^{1}$ \\ ${ }^{1}$ Cancer Research Institute, University of South China, Hengyang, Hunan 421001; \\ ${ }^{2}$ Department of Pathology, Hainan Medical University, Haikou, Hainan 571101, P.R. China
}

Received November 22, 2010; Accepted February 28, 2011

DOI: $10.3892 / \mathrm{mmr} .2011 .453$

\begin{abstract}
Diallyl disulfide (DADS), a sulfur compound derived from garlic, has been shown to have protective effects against colon carcinogenesis in several studies performed in rodent models. However, its molecular mechanism of action remains unclear. This study was designed to confirm the antiproliferative activity of DADS and to screen for differentially expressed genes induced by DADS in human colon cancer cells with the aim of exploring its possible anticancer mechanisms. The anti-proliferative capability of DADS in the HT-29 human colon cancer cells was analyzed by MTT assays and flow cytometry. The differences in gene expression between DADStreated (experimental group) and untreated (control group) HT-29 cells were identified using two-directional suppression subtractive hybridization (SSH). Semi-quantitative reverse transcription polymerase chain reaction (semi-RT-PCR) was selected to confirm the results obtained by SSH. Based on the results, a dose- and time-dependent growth inhibition was observed in the DADS-treated HT-29 cells. Forty-nine known genes and a new gene were found to be involved in the anti-proliferative effects of DADS by SSH analysis, and two cDNA libraries, DHDG and DHUG, containing both up- and down-regulated genes in colon tumor cells, were constructed. These genes were related to transduction, cell proliferation/ growth/apoptosis and secreted/extracellular matrix proteins. Semi-RT-PCR results showed an expression pattern consistent with that of the SSH analysis. In conclusion, DADS showed anti-proliferative effects on colon cancer HT-29 cells, and DHDG and DHUG genes were found to be involved in this process. Further studies on the identification and description of these genes may allow a better understanding of the protective roles of DADS in colon carcinogenesis.
\end{abstract}

Correspondence to: Professor Qi Su, Cancer Research Institute, University of South China, No. 23 Chang Sheng Western Road, Hengyang, Hunan 421001, P.R. China

E-mail: suqi1@hotmail.com

Key words: diallyl disulfide, colon cancer, suppression subtractive hybridization, gene expression, HT-29 cells

\section{Introduction}

Colon cancer is one of the major causes of cancer death worldwide (1). An understanding of the mechanisms involved in the occurrence and development of colon cancer would aid in its therapy. Epidemiological investigations have provided compelling evidence that environmental factors are modifiers in colon cancer (1-3); diet has also been shown to be an important determinant of cancer risk and tumor behavior (3-5).

Garlic consumption is very popular all over the world. Epidemiological studies have shown an inverse correlation between the consumption of garlic and colon cancer in certain areas (6). Many in vivo experiments have revealed the antitumorigenic activity of garlic or of allyl sulfur compounds from garlic (7-17).

Diallyl disulfide (DADS) is the major component of cooked garlic and an oil-soluble organosulfur compound in processed garlic that inhibits the proliferation of several human cancer cells, including breast (11), hepatoma (12), colon cancer (13) and human leukemia HL-60 cells (14). Previous studies from our laboratory revealed that DADS suppresses gastric (15) and colon cancer (16). Additionally, leukemia cell proliferation was related to DADS $(14,17)$, possibly because of its ability to induce cell cycle arrest and apoptosis, inhibit ERK, activate p38, and alter cell calcium homeostasis and gene expression. Recent results from in vitro experiments showed that the pleiotropic biological effects of DADS may be involved in the modulation of gene expression $(19,20)$. For example, with regard to apoptosis-associated genes, DADS enhances the expression of the Fas-L gene and decreases the Bag-1 gene at the mRNA level (20). However, the molecular mechanisms by which DADS exerts protective effects on tumor cells are largely unknown, thus this study was designed to confirm the anti-proliferative activity of DADS on human colon cancer cells with the aim of exploring its possible anticancer mechanisms.

\section{Materials and methods}

Cell lines and reagents. The human colon cancer cell line HT-29 and RPMI-1640 medium were purchased from China Typical Culture Center and Gibco BRL, respectively. Fetal bovine serum (FBS) was from Hangzhou Sijiqing Corp. and DADS was from Fluka. TRIzol reagent was purchased from Sangon Co. (Shanghai, China). The Poly A ${ }^{+}$RNA Purification 
Table I. Location and sequences of the optimal primers.

\begin{tabular}{lccc}
\hline Primer & PCR fragment size $(\mathrm{bp})$ & \multicolumn{1}{c}{ Sequence } & Location on cDNA \\
\hline 3'GAPDH & 287 & 5'GCCAAAAGGGTCATCATCTC3' & $406-425$ \\
5'GAPDH & 287 & 3'GTAGAGGCAGGGATGATGTTC5' & $672-692$ \\
3'ARPC3 & 392 & 5'ATCCTGCTCCTCTGGGTTGA3' & $56-75$ \\
5'ARPC3 & 392 & 3'GTGAATTGCGTTAAATACGG5' & $428-447$ \\
3'SPINT2 & 175 & 5'ACGCAGCATCCACGACTTCT3' & $424-443$ \\
5'SPINT2 & 175 & 3'TCACGGAGTTCTTTACACGG5' & $579-598$ \\
3'SOD1 & 191 & 5'AATGTGACTGCTGACAAAGATG3' & $407-428$ \\
5'SOD1 & 191 & 3'GCAAACCGAACACCACATTA5' & $578-597$ \\
3'p21, Cip1 & 241 & 5'TGGACTGGAAGGGGAAGGGAC5' & $1626-1647$ \\
5'p21, Cip1 & 241 & 3'GGAGTAGGTGGGGTAGGGAG3' & $1847-1866$ \\
3'TACSTD2 & 386 & 5'CAGTGGCAGTAAGGGCAAGC5' & $576-595$ \\
5'TACSTD2 & 386 & 3'GTAGGGAAGGAAGTGACGGG3' & $943-962$ \\
3'TRA-1 & 254 & 5'TTCTTTCTCAACTGCTTCACG3' & $568-589$ \\
5'TRA-1 & 3'TGGGTCGGTACTTCATCTAAA5' & $801-821$ \\
3'YWHAE & 354 & 5'TGTCTCACTGATTTCGTCTTCC3' & $926-948$ \\
5'YWHAE & 305 & 3'TTATCCTACGCAACCACCTT5' & $1211-1230$ \\
3'RRM1 & 305 & 5'TATTGCCCCGATGCCTACAG3' & $2026-2045$ \\
5'RRM1 & 431 & 3'GATGCCGACCTTCGTCCCAA5' & $2437-2456$ \\
3'DCBLD2 & 431 & 5'ACCTGAAAAGGGATGACTGC3' & 1529-1548 \\
5''DCBLD2 & 348 & 3'TATTAGACCACCGAGTCCGG5' & $1857-1876$ \\
3'Rps6 & 348 & 5'ACAGAAGTTGCTGCTGACGC3' & 95-114 \\
5'Rps6 & 437 & 3'CGTGGGTTCTAAGTCGCAGA5' & $512-531$ \\
\hline
\end{tabular}

kit, pGEM-T Easy Vector and JM109 bacteria were from Promega. The PCR-Select cDNA Subtraction kit, Advantage cDNA PCR kit and restriction enzyme were purchased from Clontech; Ampicillin, MTT, X-gal and IPTG were from BBI. The other chemicals used were of the purest grade available, purchased from Sigma.

Cell culture and MTT assay. A tetrazolium salt, 3-(4,5-dimethylthiazol-2-yl)-2,5-diphenyltetrazolium bromide (MTT) reduction assay was used to assess the cytotoxic effects of DADS in HT-29 cells. The cells were cultured in RPMI-1640 medium supplemented with $100 \mathrm{ml} / \mathrm{l} \mathrm{FBS}$ with the addition of $100 \mathrm{U} / \mathrm{ml}$ penicillin and $100 \mathrm{U} / \mathrm{ml}$ streptomycin. The cultured cells were plated in 96-well culture plates and incubated at $37^{\circ} \mathrm{C}$ in a humidified atmosphere of $50 \mathrm{ml} / 1 \mathrm{CO}_{2}$ in air. When these cells reached $80 \%$ confluence, the culture medium was changed to a complete medium with final concentrations of 0 , $30,60,120$ and $240 \mu \mathrm{mol} / \mathrm{l} \mathrm{DADS}$, and the cells were cultivated for an additional 12, 24 and $48 \mathrm{~h}$. Subsequently, $20 \mu \mathrm{l}$ $5 \mathrm{~g} / \mathrm{l}$ MTT solution was added to each well, and the cultures were further incubated in $100 \mu \mathrm{l}$ DMSO solution. A microplate reader was used to measure the absorbance at $570 \mathrm{~nm}$ for each well. The growth inhibition rate was calculated as follows: growth inhibition rate $=\left(1-\mathrm{A}_{570} / \mathrm{nm}\right.$ of treated cells $/ \mathrm{A}_{570} / \mathrm{nm}$ of control cells) x $100 \%$

Cell cycle analysis. HT-29 cells were grown to $80 \%$ confluence and the culture medium was replaced with complete medium with a final concentration of $0,30,60$ and $120 \mu \mathrm{mol} / 1$
DADS. After $24 \mathrm{~h}$, cells were harvested and fixed in 70\% ethanol at $4^{\circ} \mathrm{C}$ for $24 \mathrm{~h}$. Fixed cells were washed with PBS once and suspended in $1 \mathrm{ml}$ of propidium iodide (PI) staining reagents $(20 \mathrm{mg} / \mathrm{l}$ ribonuclease and $50 \mathrm{mg} / \mathrm{l} \mathrm{PI})$. Samples were incubated in the dark for $30 \mathrm{~min}$ before cell cycle analysis. The distribution of cells in the cell cycle was measured by a flow cytometer.

Total RNA and mRNA isolation. Total RNA was isolated from DADS-treated $(120 \mu \mathrm{M})$ and -untreated cells using TRIzol Reagent $^{\mathrm{TM}}$ according to the manufacturer's instructions. Poly $\mathrm{A}^{+}$ mRNA was isolated from total RNA samples with mini-oligo (dT) cellulose spin columns; synthesis of $1.2 \mu \mathrm{g}$ of mRNA, cDNA was performed using a PCR-Select cDNA Subtraction kit according to the manufacturer's recommendations.

Construction of subtracted cDNA library. SSH (21) was performed using the Clontech PCR-Select cDNA Subtraction kit and advantage polymerase mix according to the manufacturer's instructions, with slight modifications. Briefly, the cDNAs obtained as described above were digested with restriction enzyme $R s a$ I to obtain the blunt-ends necessary for adaptor ligation. cDNA subtraction was carried out in two directions, one for use in the test group as the driver and the control group as the tester, and the other for use in the control group as the driver and the test group as the tester. The efficiency of cDNA subtraction was evaluated by comparing the expression levels of glyceraldehyde-3-phosphate dehydrogenase (GAPDH), a housekeeping gene, in the subtracted cDNA 
fragment by RT-PCR. The subtracted cDNA fragments were then inserted into pGEM-T Easy Vector and transformed into Escherichia coli strain DH5a, and two SSH cDNA libraries were constructed.

Sequencing of the subtracted cDNA clones and bioinformatics analysis. From the two SSH libraries, 200 white colonies were randomly selected and incubated in LB medium containing $100 \mathrm{mg} / \mathrm{ml}$ ampicillin overnight at $37^{\circ} \mathrm{C}$. Sequencing was carried out at Shanghai Sangon with the M13 reverse primer (included in the Advantage cDNA PCR kit). Nucleic acid homology searches for the cDNA clones were performed by comparison to the NCBI RefSeq, GenBank, and expressed sequence tags databases (dbEST) using BLAST. All database versions were taken as a snapshot from public releases available as of April, 2010.

Semi-quantitative reverse transcription-polymerase chain reaction analysis (RT-PCR). Total RNA from DADS-treated and -untreated control cells after cultivation were reverse transcribed to cDNA by Superscript II reverse transcriptase in a 20-ml reaction volume. The PCR reaction was carried out in $25 \mu \mathrm{l}$ of buffer $(16.6 \mathrm{mM}$ ammonium sulfate, $67 \mathrm{mM}$ Tris-HCl, $\mathrm{pH} 8.8,0.01 \%$ Tween-20) containing $0.2 \mathrm{mM}$ dNTP mix, $0.25 \mu \mathrm{M}$ of each primer and 1 unit Taq DNA polymerase, and subjected to 30 cycles of amplification at $94^{\circ} \mathrm{C}$ for $30 \mathrm{sec}$, $60^{\circ} \mathrm{C}$ for $30 \mathrm{sec}$ and $72^{\circ} \mathrm{C}$ for $40 \mathrm{sec}$. GAPDH was used as an internal control in each PCR amplification process. The PCR primers for individual genes (listed in Table I) were synthesized by Sangon Ltd. For RT-PCR, the primer pairs were designed to generate a DNA fragment spanning an exon-exon junction. The PCR products were separated by electrophoresis on $1.5 \%$ agarose gel stained with ethidium bromide, and photographed under UV light. The images obtained were processed for quantitative analysis using Gel-Pro analyzer software version 3.1 (Media Cybernetics, Inc., Silver Spring, MD, USA). The densitometric measurements of the bands of the testing genes from each pair of DADS-treated/DADSuntreated sample were normalized to those of GAPDH in the same sample. The sample was considered positive if the ratio was >1.5 when comparing the data from DADS-treated HT-29 to DADS-untreated HT-29 cells.

Statistical analysis. Results were analyzed by SPSS17.0 statistical software. Data were expressed as the mean \pm SD. Comparisons between groups were made by one-way ANOVA (with LSD for post hoc analysis) or the $\chi^{2}$ test. $\mathrm{P}<0.05$ was considered statistically significant.

\section{Results}

Cytotoxic effect of DADS on HT-29 cells. To confirm the antiproliferative activity of DADS, the cytotoxic effects of DADS on HT-29 cells were measured by MTT assays. As shown in Fig. 1, a dose-dependent (Fig. 1A) and time-dependent (Fig. 1B) growth inhibition was observed when cells were exposed to various concentrations of DADS for 12, 24 or $48 \mathrm{~h}$. Treatment with 30,60, 120 and $240 \mu \mathrm{M}$ DADS for $24 \mathrm{~h}$ suppressed HT-29 cell growth by 5.3, 23.1, 45.6 and $68.3 \%$ $(\mathrm{P}<0.05$ vs. control), respectively; treatment with $120 \mu \mathrm{M}$
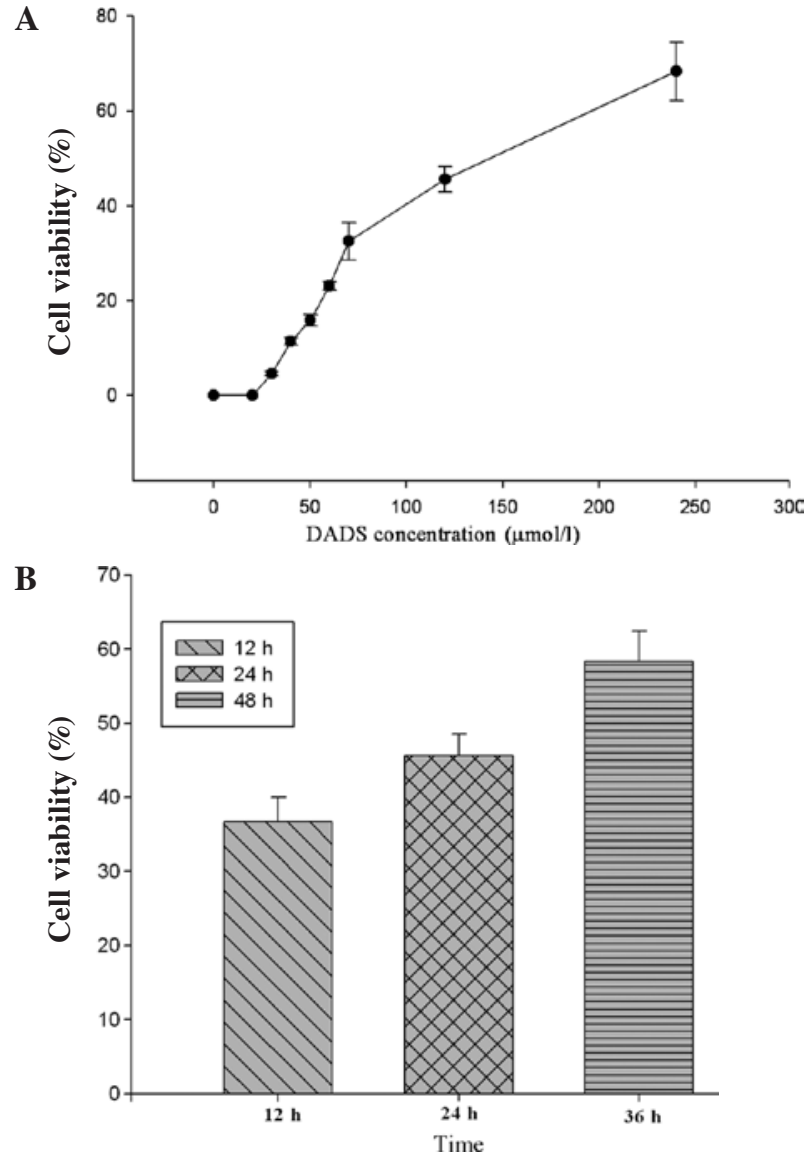

Figure 1. DADS showed a dose-dependent (A) and time-dependent (B) inhibitory effect on HT-29 cells.

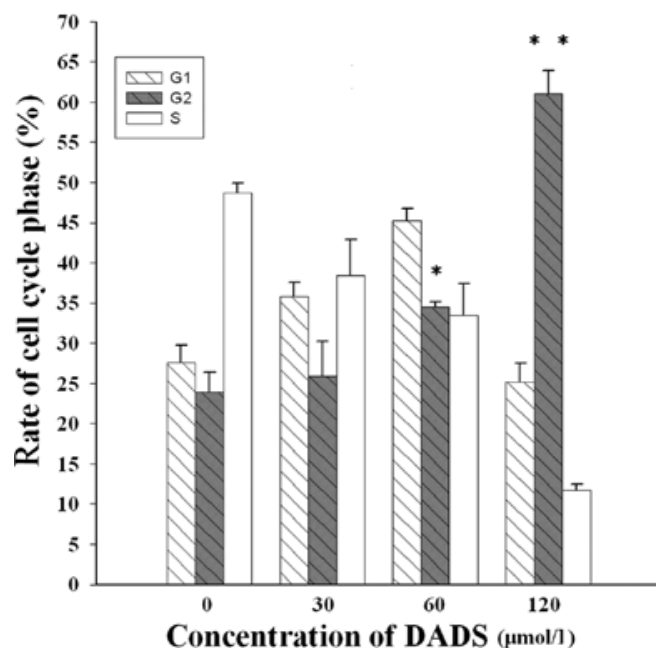

Figure 2. Effect of DADS on the cell-cycle distribution of HT-29 cells by flow cytometry. ${ }^{*} \mathrm{P}<0.05$ vs. control, ${ }^{* *} \mathrm{P}<0.01$ vs. control.

DADS for 12, 24 and $48 \mathrm{~h}$ suppressed HT-29 cell growth by 36.7, 45.6 and $58.7 \%$ ( $\mathrm{P}<0.05$ vs. control), respectively. The concentration of DADS that induced the half maximal effect $\left(\mathrm{ED}_{50}\right)$ was $\sim 120 \mu \mathrm{M}$ after treatment for $24 \mathrm{~h}$.

Flow cytometric analysis of cell cycle distribution. To further examine the anti-proliferative effect of DADS, cell cycle 


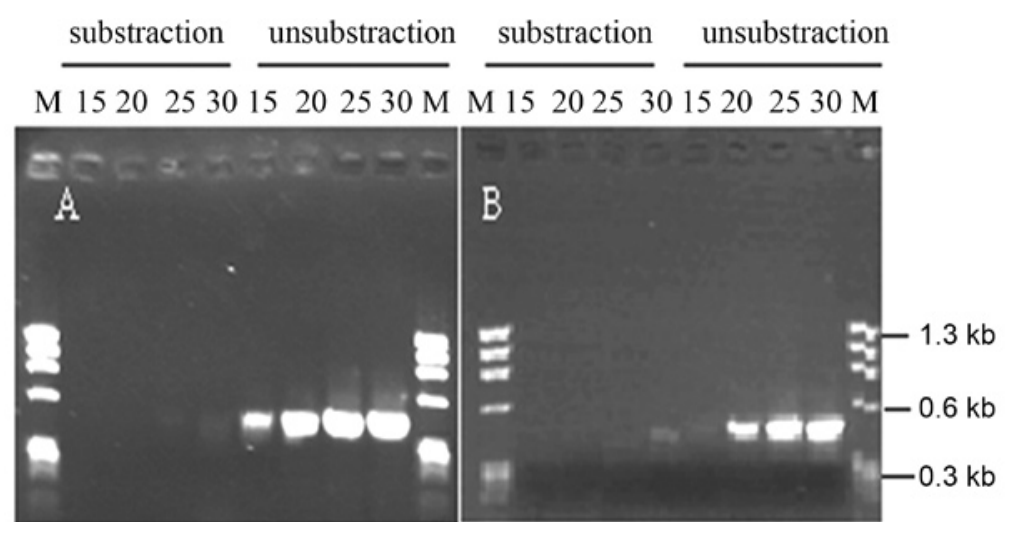

Figure 3. Evaluation of the efficiency of suppression subtractive hybridization. PCR amplification of the housekeeping gene GAPDH verifying the loss of nondifferentially expressed cDNA following the SSH experiment. PCR from the subtracted cDNA pool was positive following 30 cycles, while only 15 cycles were necessary to detect GAPDH in the non-subtracted cDNA pool. As a difference of 5 cycles roughly corresponds to a 20 -fold cDNA concentration difference, this indicates that the SSH experiment was successfully performed. (A) Forward-subtracted cDNA pool. (B) Reverse-subtracted cDNA pool M, marker, cycles $15,20,25$ and 30 .

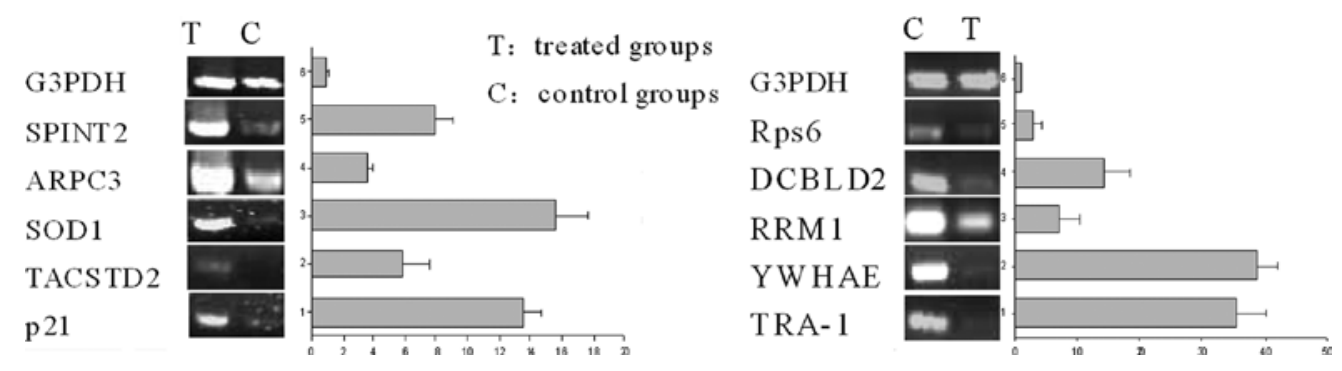

Figure 4. Semiquantitative reverse transcriptase-mediated PCR on DADS-treated and untreated HT-29 cells. Verification of differential expression of ten arbitrarily selected clones was performed by semi-quantitative RT-PCR. RNA samples were normalized using the housekeeping gene GAPDH, which did not show a differential signal between the untreated and treated samples.

distribution was detected by flow cytometry after treatment with $0,30,60$ and $120 \mu \mathrm{M}$ DADS for $24 \mathrm{~h}$, and the percentage of cells in the G2/M-phase was found to be 23.6, 25.9, 39.7 and $61.0 \%$, respectively (Fig. 2). The proportion of cells in the $\mathrm{G} 2 / \mathrm{M}$ phase after treatment with $120 \mu \mathrm{M}$ DADS for $24 \mathrm{~h}$ was $61.0 \%$, three times higher than that observed in untreated cells $(23.6 \%)(\mathrm{P}<0.01)$. No significant difference in the percentage was observed between the $\mathrm{G} 1$ and $\mathrm{S}$ phase or between different treatment lengths. These results indicated that DADS induced cell cycle arrest in the G2/M-phase in HT-29 cells in a concentration-independent manner. Thereafter, we used the concentrations of $120 \mu \mathrm{M}$ in the subsequent SSH analysis.

SSH screening of mRNAs induced by DADS exposure. Test groups of HT-29 cells were incubated in medium containing $120 \mu \mathrm{M}$ DADS for $24 \mathrm{~h}$, then both the DADS-treated and -untreated cells were pooled before screening for the DADSinducible genes by SSH. Two cDNA libraries containing up- and down-regulated genes in the tumor cells were constructed: DHUG (the up-regulated genes group induced by DADS in the HT-29 cells) and DHDG (the down-regulated genes group induced by DADS in the HT-29 cells). The subtraction efficiency was evaluated using the housekeeping gene GAPDH. The amount of GAPDH transcripts was reduced 40-fold after subtraction (Fig. 3). After ensuring that the housekeeping gene had been extensively removed from the subtraction reactions, the subtracted cDNA was cloned into a pGEM-T easy vector for screening.

Approximately 500 colonies containing cDNA fragments potentially representing DADS-inducible mRNA were obtained after the SSH screening, of which 120 colonies were randomly selected and amplified for sequencing. As a result, 40 genes that appeared at least twice were identified. All were identical to known human genes, including a new EST. The genes were categorized into three groups based on their biological functions (Tables II and III). All the EST sequences are available from NCBI (GenBank: HO004746-HO004785).

Expression pattern of genes induced by DADS exposure. To confirm the results of SSH, ten different clones were randomly selected for semi-quantitative RT-PCR. The primer sequences used are summarized in Table I. Fig. 4 shows the results of RT-PCR; the signals were normalized to the housekeeping gene GAPDH for comparisons. It was found that the mRNA levels of ARPC3, SPINT2, SOD1, p21 and TACSTD2 in the DADS-treated HT-29 cells were 3.52-, 7.98-, 15.6-, 13.47- and 5.92-fold higher than those in the primary cultured cells $(\mathrm{P}<0.05)$, respectively. Correspondingly, the expression of Rps6, DCBLD2, RRM1, YWHAE and TRA-1 in primary cultured HT-29 cells was 2.87-, 14.31-, 7.34-, 35.17- and 30.29-fold higher than that in DADS-treated cells $(\mathrm{P}<0.05)$, respectively. GAPDH levels were unchanged. 
Table II. Up-regulated genes induced by DADS exposure in HT-29 cells.

\begin{tabular}{|c|c|c|}
\hline Category & $\begin{array}{c}\text { EST accession no. } \\
\text { (GenBank })\end{array}$ & $\begin{array}{l}\text { Name of the } \\
\text { proteins/genes }\end{array}$ \\
\hline \multirow[t]{12}{*}{$\begin{array}{l}\text { Cell cycle and } \\
\text { metabolism }\end{array}$} & HO004746 & p21 \\
\hline & HO004747 & MRPS27 \\
\hline & HO004748 & MM1 \\
\hline & HO004749 & galectin 8 \\
\hline & HOO04750 & ARPC3 \\
\hline & HO004751 & DNCL1 \\
\hline & HO004752 & SOD1 \\
\hline & HO004753 & $\begin{array}{l}\text { Citrate } \\
\text { synthase }\end{array}$ \\
\hline & HO004754 & HNRPAB \\
\hline & HO004755 & FTH1 \\
\hline & HO004756 & SPINT2 \\
\hline & HO004757 & UBA52 \\
\hline \multirow{9}{*}{$\begin{array}{l}\text { Apoptosis and } \\
\text { signaling system }\end{array}$} & & \\
\hline & HO004758 & TACSTD2 \\
\hline & HO004759 & S100A6 \\
\hline & HO004760 & PSMD12 \\
\hline & HO004761 & GNB1 \\
\hline & HO004762 & GPCR175 \\
\hline & HO004763 & NSFL1C \\
\hline & HO004764 & MTO1 \\
\hline & HO004765 & DPCD \\
\hline \multicolumn{3}{|l|}{ Others } \\
\hline & HO004766 & $\begin{array}{l}\text { Ribosomal } \\
\text { protein S3 }\end{array}$ \\
\hline & HO004767 & KRT80 \\
\hline & HO004768 & ANKRD39 \\
\hline & HO004769 & RPL35A \\
\hline & HO004770 & $\begin{array}{l}\text { DHUG25 } \\
\text { (new EST) }\end{array}$ \\
\hline
\end{tabular}

\section{Discussion}

DADS is a major organosulphur compound present in garlic, with an anti-mitotic potential against colon neoplasic lesions (in vivo) and colon tumor cell growth (in vitro), that influences the metabolism, adherence and cell cycle of HT-29 colon carcinoma cells $(13,16)$. In this study, the anti-proliferative activity and a dose-dependent growth inhibition was observed when colon cancer HT-29 cells were exposed to various concentrations of DADS.

To better understand the molecular mechanism involved in the antitumorigenic effects of DADS, the SSH technique, which enables the identification of rarely expressed, but specific, DADS-inducible genes (21), was applied. Forty different DADS-inducible genes, including a new EST, were identified. These identified genes were classifiable into three categories: genes involved in the signaling system and apoptosis, genes related to the cell cycle and metabolism and genes
Table III. Down-regulated genes induced by DADS exposure in HT-29 cells.

\begin{tabular}{|c|c|c|}
\hline Category & $\begin{array}{c}\text { EST accession no. } \\
\text { (GenBank) }\end{array}$ & $\begin{array}{l}\text { Name of the } \\
\text { proteins/genes }\end{array}$ \\
\hline \multirow[t]{5}{*}{$\begin{array}{l}\text { Cell cycle and } \\
\text { metabolism }\end{array}$} & HO004772 & PABPC1 \\
\hline & HO004773 & RAC1 \\
\hline & HO004774 & RRM1 \\
\hline & HO004775 & ATP6AP1 \\
\hline & HO004776 & TRIP13 \\
\hline \multirow[t]{2}{*}{$\begin{array}{l}\text { Apoptosis and } \\
\text { signaling system }\end{array}$} & HO004777 & ATP1A1 \\
\hline & HO004778 & YWHAE \\
\hline \multirow[t]{8}{*}{ Others } & & \\
\hline & HO004779 & $\begin{array}{l}\text { Homo sapiens } \\
\text { FLJ25150 fis }\end{array}$ \\
\hline & HO004780 & TRA1 \\
\hline & HO004781 & HSP90B1 \\
\hline & HO004782 & TMED5 \\
\hline & HO004783 & NCAPD3 \\
\hline & HO004784 & RPS6 \\
\hline & HO004785 & $\begin{array}{l}\text { Heat shock } \\
\text { protein } 8\end{array}$ \\
\hline
\end{tabular}

with unknown functions (Tables II and III). In order to confirm the differential expression of the subtracted genes in DHDG and DHUG, ten sequences in DADS-treated and -untreated HT-29 cells were randomly detected by semi-quantitative RT-PCR. The positive result indicated that SSH is a powerful method for the detection and comparison of differential gene expression.

Previous studies in our laboratory showed that DADS arrests unsynchronized tumor cells in the G2/M phase of the cell cycle, inhibits cell proliferation and induces tumor cell apoptosis by inhibiting the ERK signaling pathways, activating the p38 signaling pathways, or by increasing the expression of p21 $1^{\text {waf/cip }}$ (14-17). In the present study, we observed that DADS up-regulated the expression of p21 and MM1 and suppressed YWHAE and RRM1.

P21 encodes a potent cyclin-dependent kinase inhibitor (22). The encoded protein binds to and inhibits the activity of the cyclin-CDK2 or -CDK4 complexes, and thus functions as a regulator of cell cycle progression. Cell cycle arrest can be caused by increasing the expression of p21 waf/cip $(22,23)$. In certain tumor cell lines, it was possible to alter the phase of cell cycle arrest caused by the inhibition of c-Myc by depleting the tumor suppressor protein p21 $1^{\text {waf/cip }}(24)$. MM1 is associated with c-myc and is believed to supress the transcriptional activity of c-myc (25). Evidence indicates that the expression of p21 and MM1 is capable of inducing cell cycle arrest and inhibiting neoplastic cell growth $(26,27)$.

YWHAE (other designations: $14-3-3 \varepsilon$ and $14-3-3 \varepsilon$ ) product belongs to the 14-3-3 family of proteins and interacts with the CDC25 phosphatases and RAF1, RS1, DP3 and E2F proteins. This suggests that it plays a role in diverse biochemical 
activities related to signal transduction, such as cell division, apoptosis and the regulation of insulin sensitivity (28-30). Studies have suggested that the cleavage of YWHAE during apoptosis promotes cell death and induces cell cycle G2 arrest (30); while apoptosis was induced by the expression of E2F, it was less significant in the presence of YWHAE. RRM1, a $\mathrm{pRb} / \mathrm{E} 2 \mathrm{~F}$ cell-cycle target gene (31), encodes one of two nonidentical subunits that constitute ribonucleoside-diphosphate reductase, an enzyme essential for the production of deoxyribonucleotides prior to DNA synthesis in the S phase of dividing cells. The decrease in RRM1 expression supresses cancer cell proliferation by reducing DNA synthesis in the $S$ phase of dividing cells (32). Our results were consistent with previous data. These studies indicated that the expression of p21, MM1, YWHAE and RRM1 may be involved in DADSinduced cell apoptosis and anti-proliferative effects.

The effects of garlic on the activities of a number of antioxidant enzymes have been studied $(19,33)$, and it has been demonstrated that garlic scavenges free radicals and is a successful antioxidant, wherein DADS has the potency to activate the antioxidant enzymes (19). In the SSH performed here, two genes, SOD1 and FTH1, were found to be associated with the antioxidant.

Free iron is toxic because it facilitates the generation of highly reactive oxy radical species that damage cellular constituents. Balancing the deleterious and beneficial effects of iron is an essential aspect of cell survival $(34,35)$. Ferritin plays a key role in the cellular metabolism of iron for almost all organisms. Mammalian ferritins are commonly heteropolymers of 24 subunits of $\mathrm{H}$ and $\mathrm{L}$ types. Functionally, the $\mathrm{H}$-chain contains a dinuclear ferroxidase center of $\mathrm{A}$ and $\mathrm{B}$ binding sites. This center facilitates the rapid oxidation of $\mathrm{Fe}^{2+}$ by $\mathrm{O}_{2}$ or $\mathrm{H}_{2} \mathrm{O}_{2}$, followed by $\mathrm{Fe}^{3+}$ hydrolysis and mineralization to form the iron core within the protein interior $(40,41)$. Overexpression of human $\mathrm{H}$-chain ferritin (HuHF) is known to impart a degree of protection to cells against oxidative stress $(35,36)$.

The protein encoded by superoxide dismutase-1 (SOD1) binds copper and zinc ions and is one of two isozymes responsible for destroying free superoxide radicals in the body. The encoded isozyme is a soluble cytoplasmic protein with an essential role in antioxidant defense (37). The expression of SOD1 reduces cellular resistance to oxidative stress, and the silencing of its expression is related to various diseases (38). The functional status of SOD1 is considered a reliable index of the ability of an organism to withstand various pathological conditions (38). The increased expression of SOD1 and FTH1 in HT-29 cells after DADS exposure suggest their role in the antioxidant effect of DADS.

Numerous data have shown that calcium reduces the risk of colorectal cancer $(39,40)$. DADS induces the elevation of cytosolic $\mathrm{Ca}^{2+}$ and activates the cell apoptotic program $(18,19)$. In the present study, four genes, including S100 A6, TACSTD2, PABP (found in DHUG) and DNCL1 (found in DHDG), were potentially related to cell apoptosis and cytosolic $\mathrm{Ca}^{2+}$.

TACSTD2 is a member of a family including at least two type I membrane proteins that transduce an intracellular calcium signal and act as a cell surface receptor. TACSTD2 induces $\mathrm{Ca}^{2+}$ release from intracellular stores (41). S100A6 is a $10-\mathrm{kDa}$ protein that belongs to the S100 subfamily of
EF-hand: calcium binding proteins that may be involved in the regulation of the proliferation of normal and tumor tissues in a calcium-dependent manner (42). S100A6 may also be related to increased expression after calcium exposure (43). The activity of PABP and DNCL1 is believed to be related to cell apoptosis and cytosolic $\mathrm{Ca}^{2+}$ levels $(44,45)$. This is in agreement with our findings, supporting the hypothesis that DADS induces an increase in cytosolic $\mathrm{Ca}^{2+}$ and activates the cell apoptotic program.

Recent studies have reported that the ability of DADS to up-or down-regulate the mRNA expression of some genes is related to its signal pathway $(17-20,46)$. Our results revealed that DADS may be involved in mediating multiple signal pathways in HT-29 cells by up-regulating the expression of GPCR175, GNB1, PSMD12, S100A6, TACSTD2 or by suppressing ATP1A1, YWHAE and FLJ25150 fis.

Other genes detected by SSH were UBA52, FTA1, MRPS27 and LGALS28, whose functions were unclear. However, they may also be involved in the antitumorigenic effects of DADS in the HT-29 cells. In addition, we found a new EST expressed in DADS-treated HT-29 cells, DHUG25, showing a high sequence homology with the genes for Homo sapiens oligonucleotide/oligosaccharide-binding fold containing 1 mRNA. However, its function is also unknown.

In conclusion, the anti-proliferative activity of DADS in colon cancer HT-29 cells is associated with numerous genes that are differentially expressed and involved in various physiological systems. Further investigation of the induction of these genes at the protein and functional levels is necessary to support our findings.

\section{Acknowledgements}

This study was supported by the National Natural Science Foundation (no. 31000629).

\section{References}

1. Narayan S and Roy D: Role of APC and DNA mismatch repair genes in the development of colorectal cancers. Mol Cancer 2: 41-56, 2003.

2. Promthet SS, Pientong C, Ekalaksananan T, Wiangnon S, Poomphakwaen K, Songserm N, Chopjitt P, Moore MA and Tokudome S: Risk factors for colon cancer in Northeastern Thailand: interaction of MTHFR codon 677 and 1298 genotypes with environmental factors. J Epidemiol 20: 329-338, 2010.

3. Forte A, De Sanctis R, Leonetti G, Manfredelli S, Urbano V and Bezzi M. Dietary chemoprevention of colorectal cancer. Ann Ital Chir 79: 261-272, 2008.

4. Pearson JR, Gill CI and Rowland IR: Diet, fecal water, and colon cancer development of a biomarker. Nutr Rev 67: 509-526, 2009.

5. Marshall JR: Nutrition and colon cancer prevention. Curr Opin Clin Nutr Metab Care 12: 539-543, 2009.

6. Khanum F, Anilakumar KR and Viswanathan KR: Anticarcinogenic properties of garlic: a review. Crit Rev Food Sci Nutr 44: 479-488, 2004

7. Malki A, El-Saadani M and Sultan AS: Garlic constituent diallyl trisulfide induced apoptosis in MCF7 human breast cancer cells. Cancer Biol Ther 8: 2175-2185, 2009.

8. De Martino A, Filomeni G, Aquilano K, Ciriolo MR and Rotilio G: Effects of water garlic extracts on cell cycle and viability of HepG2 hepatoma cells. J Nutr Biochem 17: 742-749, 2006.

9. Xiao D, Zeng Y, Hahm ER, Kim YA, Ramalingam S and Singh SV: Diallyl trisulfide selectively causes Bax- and Bak-mediated apoptosis in human lung cancer cells. Environ Mol Mutagen 50: 201-212, 2009. 
10. Wang YB, Qin J, Zheng XY, Bai Y, Yang K and Xie LP: Diallyl trisulfide induces Bcl-2 and caspase-3-dependent apoptosis via downregulation of Akt phosphorylation in human T24 bladder cancer cells. Phytomedicine 17: 363-368, 2010.

11. Jun Z, Suzuki M, Xiao J, Wen J, Talbot SG, Li GC and Xu M: Comparative effects of natural and synthetic diallyl disulfide on apoptosis of human breast-cancer MCF-7 cells. Biotechnol Appl Biochem 52: 113-119, 2009.

12. Wen J, Zhang Y, Chen X, Shen L, Li GC and Xu M: Enhancement of diallyl disulfide-induced apoptosis by inhibitors of MAPKs in human HepG2 hepatoma cells. Biochem Pharmacol 68: 323-331, 2004.

13. Song JD, Lee SK, Kim KM, Park SE, Park SJ, Kim KH, Ahn SC and Park YC: Molecular mechanism of diallyl disulfide in cell cycle arrest and apoptosis in HCT-116 colon cancer cells. J Biochem Mol Toxicol 23: 71-79, 2009.

14. Zhao J, Huang WG, He J, Tan H, Liao QJ and Su Q: Diallyl disulfide suppresses growth of HL-60 cell through increasing histone acetylation and p21WAF1 expression in vivo and in vitro. Acta Pharmacol Sin 27: 1459-1466, 2006.

15. Ling H, Zhang LY, Su Q, Song Y, Luo ZY, Zhou XT, Zeng X, $\mathrm{He}$ J, Tan $\mathrm{H}$ and Yuan JP: Erk is involved in the differentiation induced by diallyl disulfide in the human gastric cancer cell line MGC803. Cell Mol Biol Lett 11: 408-423, 2006.

16. Liao QJ, Su J, He J, Song Y, Tang HL and Su Q: Effect of diallyl disulfide on cell cycle arrest of human colon cancer SW480 cells. Ai Zheng 28: 138-141, 2009.

17. Tan H, Ling H, He J, Yi L, Zhou J, Lin M and Su Q: Inhibition of ERK and activation of p38 are involved in diallyl disulfide induced apoptosis of leukemia HL-60 cells. Arch Pharm Res 31: 786-793, 2008

18. Park EK, Kwon KB, Park KI, Park BH and Jhee EC: Role of $\mathrm{Ca}(2+)$ in diallyl disulfide-induced apoptotic cell death of HCT-15 cells. Exp Mol Med 34: 250-257, 2002.

19. Tsai CW, Chen HW, Yang JJ, Sheen LY and Lii CK: Diallyl disulfide and diallyl trisulfide up-regulate the expression of the pi class of glutathione S-transferase via an AP-1-dependent pathway. J Agric Food Chem 55: 1019-1026, 2007.

20. Lin M, Xie HL, Su Q, Zhou JG, Tan H, Yi L, Tang HL, Huang Y and Shi Y: Effects of diallyl disulfide on differential expression of apoptosis-associated genes in leukemia cell line HL-60. Ai Zheng 26: 351-356, 2007.

21. Rebrikov DV, Desai SM, Siebert PD and Lukyanov SA: Suppression subtractive hybridization. Methods Mol Biol 258: 107-134, 2004

22. Xiong Y, Hannon GJ, Zhang H, Casso D, Kobayashi R and Beach D: p21 is a universal inhibitor of cyclin kinases. Nature 366: 701-704, 1993.

23. Levkau B, Koyama H, Raines EW, Clurman BE, Herren B, Orth K, Roberts JM and Ross R: Cleavage of p21 Cip1/Wafl and p2 $7^{\text {Kipl }}$ mediates apoptosis in endothelial cells through activation of Cdk2: role of a caspase cascade. Mol Cell 1: 553-563, 1998.

24. Gartel AL and Tyner AL: The role of the cyclin-dependent kinase inhibitor p21 in apoptosis. Mol Cancer Ther 1: 639-649, 2002

25. Wang H, Mannava S, Grachtchouk V, Zhuang D, Soengas MS, Gudkov AV, Prochownik EV and Nikiforov MA: c-Myc depletion inhibits proliferation of human tumor cells at various stages of the cell cycle. Oncogene 27: 1905-1915, 2008.

26. Mori K, Maeda Y, Kitaura H, Taira T, Iguchi-Ariga SM and Ariga H: MM-1, a novel c-Myc-associating protein that represses transcriptional activity of c-Myc. J Biol Chem 273: 29794-29800, 1998.

27. Watanabe K, Ozaki T, Nakagawa T, Miyazaki K, Takahashi M, Hosoda M, Hayashi S, Todo S and Nakagawara A: Physical interaction of p73 with c-Myc and MM1, a c-Myc-binding protein, and modulation of the p73 function. J Biol Chem 277: 15113-15123, 2002.
28. Jin DY, Lyu MS, Kozak CA and Jeang KT: Function of 14-3-3 proteins. Nature 382: 308, 1996.

29. Elder RT, Yu M, Chen M, Zhu X, Yanagida M and Zhao Y: HIV-1 Vpr induces cell cycle G2 arrest in fission yeast (Schizosaccharomyces pombe) through a pathway involving regulatory and catalytic subunits of PP2A and acting on both Weel and Cdc25. Virology 287: 359-370, 2001.

30. Milton AH, Khaire N, Ingram L, O'Donnell AJ and La Thangue NB: 14-3-3 proteins integrate E2F activity with the DNA damage response. EMBO J 25: 1046-1057, 2006.

31. Cayrol C, Lacroix C, Mathe C, Ecochard V, Ceribelli M, Loreau E, Lazar V, Dessen P, Mantovani R, Aguilar L and Girard JP: The THAP-zinc finger protein THAP1 regulates endothelial cell proliferation through modulation of $\mathrm{pRB} / \mathrm{E} 2 \mathrm{~F}$ cell-cycle target genes. Blood 109: 584-594, 2007.

32. Parker NJ, Begley CG and Fox RM: Human gene for the large subunit of ribonucleotide reductase (RRM1): functional analysis of the promoter. Genomics 27: 280-285, 1995.

33. Das A, Banik NL and Ray SK: Garlic compounds generate reactive oxygen species leading to activation of stress kinases and cysteine proteases for apoptosis in human glioblastoma T98G and U87MG cells. Cancer 110: 1083-1095, 2007.

34. Harrison PM and Arosio P: The ferritins: molecular properties, iron storage function and cellular regulation. Biochim Biophys Acta 1275: 161-203, 1996.

35. Zhao G, Arosio P and Chasteen ND: Iron(II) and hydrogen peroxide detoxification by human H-chain ferritin. An EPR spin-trapping study. Biochemistry 45: 3429-3436, 2006.

36. Bartnikas TB and Gitlin JD: Mechanisms of biosynthesis of mammalian copper/zinc superoxide dismutase. J Biol Chem 278: 33602-33608, 2003

37. Noor R, Mittal S and Iqbal J: Superoxide dismutase - applications and relevance to human diseases. Med Sci Monit 8: RA210-RA215, 2002

38. Jaffrey SR and Snyder SH: PIN: an associated protein inhibitor of neuronal nitric oxide synthase. Science 274: 774-777, 1996.

39. Moyad MA: The potential benefits of dietary and/or supplemental calcium and vitamin D. Urol Oncol 21: 384-391, 2003.

40. Rodland KD: The role of the calcium-sensing receptor in cancer. Cell Calcium 35: 291-295, 2004.

41. Ripani E, Sacchetti A, Corda D and Alberti S: Human Trop-2 is a tumor-associated calcium signal transducer. Int J Cancer 76: 671-676, 1998

42. Emberley ED, Murphy LC and Watson PH: S100 proteins and their influence on pro-survival pathways in cancer. Biochem Cell Biol 82: 508-515, 2004

43. Shin HJ, Park KK, Lee BH, Moon CK and Lee MO: Identification of genes that are induced after cadmium exposure by suppression subtractive hybridization. Toxicology 191: 121-131, 2003.

44. Marissen WE, Triyoso D, Younan P and Lloyd RE: Degradation of poly(A)-binding protein in apoptotic cells and linkage to translation regulation. Apoptosis 9: 67-75, 2004.

45. Yang Z, Vadlamudi RK and Kumar R: Dynein light chain 1 phosphorylation controls macropinocytosis. J Biol Chem 280: 654-659, 2005

46. Yuan JP, Wang GH, Ling H, Su Q, Yang YH, Song Y, Tang RJ, Liu Y and Huang C: Diallyl disulfide-induced G2/M arrest of human gastric cancer MGC803 cells involves activation of p38 MAP kinase pathways. World J Gastroenterol 10: 2731-2734, 2004. 